\title{
A PRELIMINARY INVESTIGATION OF QUALITY METRICS AND PERFORMANCE FOR SELECTED INSTITUTIONS DELIVERING TECHNOLOGY MEDIATED HIGHER EDUCATION
}

\author{
Suhong Li, Bryant University, sli@bryant.edu \\ Kamel Rouibah, Kuwait University, ghallawy@gmail.com \\ Hal Records, Bryant University, hrecords@bryant.edu \\ Robert Behling, Arrowrock Industries, behlingr@hotmail.com
}

\begin{abstract}
The $21^{\text {st }}$ century has brought about significant change to both business organizations and educational institutions. One of the more important changes in delivering higher education is the development and growth of technology mediated higher education (online programs), delivered by both non-profit and for-profit college and university programs. These programs provide students with expanded opportunities to further their education and have enrolled hundreds of thousands of students in courses of study. This study assesses business school programs offering technology mediated higher education using five quality metrics: 1) external review and accreditation; 2) affordability; 3) admissions and graduation; 4) online students reviews and 5) selected online education quality issues for five technology mediated programs. The results show that among the five selected online programs, they all receive some type of accreditation, have low cost per credit and have a low or no admission standards. The areas that the students most likely discuss in the online reviews include professor, advisor, financial aid, job, and experience. A sentiment analysis of 3,596 student online reviews shows that more than half of the reviews are positive, and the average sentiment score is close to 1 (on a scale of -5 to +5 ).
\end{abstract}

Keywords: Technology Mediated Higher Education, Online Education Sentiment Analysis

\section{INTRODUCTION}

General Electric is facing trying times. The company has been successful for more than a century. Recently, however, their corporate business model has not produced the positive results they have come to expect. Perhaps it is time for GE to begin thinking about an organizational change. The challenge of changing anything is management reluctance to address environment changes where a previously successful business model may no longer be effective (CNN Wire, 2018). To lead and sustain growth, all organizations need to constantly challenge the status quo as they strive to meet new challenges (Comstock, 2018).

There are clear parallels with higher education. Most colleges and universities have relied on traditional classroom delivery methods found in brick and mortar institutions. With the rapid development of technology, the changing demographics and wider age groups, and new requirements of $\mathrm{Z}$ generations and global living arrangements for college and university students, the traditional fixed classroom/lecture model may no longer provide a competitive advantage for many traditional universities. Is it time to reset their model, to more fully embrace technology in the delivery of education? Many universities such as Southern New Hampshire University and University of Phoenix are adapting to the times by focusing on technology mediated education. Other educational institutions struggle to retain the status quo, may no longer appeal to the modern student, and they ultimately may disappear.

Digital learning extends, connects and expands the learning experience, offering interactive tools and content that engages and motivates students (Pearson2, 2018). There is support for more thoughtful use of more technology in higher education. In a recent study (Google, 2018), about 2/3 of the faculty surveyed indicated strong support for utilizing more technology, and more than $2 / 3$ of the respondents indicated they liked to experiment with new teaching methods and tools. The majority of responding faculty who have taught online 


\section{Issues in Information Systems \\ Volume 20, Issue 1, pp. 108-118, 2019}

report it improved them as instructors, and $70 \%$ of students surveyed prefer courses that integrate online components (Google, 2018). A study by Siau and Chen (2016) found that many students prefer to interact with others using technology. Walk into any restaurant, waiting room, or airport and many of the people waiting will be looking down and activating the keyboard on their phone, texting, reading e-mail, accessing web sites and even reviewing menus or flight schedules.

\section{TECHNOLOGY MEDIATED EDUCATION}

The transformation potential in higher education for technology mediated education to change the way education is delivered is huge. Traditionally, educational delivery systems were either in print form or what can generally be described as face-to-face interaction through lectures, video, group projects and independent exploration and investigation. Most of these delivery methods have been with us for hundreds of years and have generally served, and continue to serve, the educational process well.

But it is clear with the introduction of technology such as the internet and social media that times are changing, and with this change comes a new form of student. Today's students have been brought up doing interactive and technology driven activities: video games; text messages; social media; and e-mail; almost anything they want is immediately available on demand from a service (that we can term the fast food culture), a commercial supplier or through the internet. Constant electronic stimulation is a way of life today, and traditional educational methods such as lectures often fall short in keeping a student's attention.

Technology mediated education includes coursework entirely delivered on the web, computer assisted learning utilizing any technology, and coursework where the learner's interaction with learning materials, peers and instructor are through utilizing advanced information technologies (Saadé et al, 2011). It includes learning that is aided or entirely accomplished with the use of computer-based technology, including distance learning and blended learning. Many colleges and universities are implementing programs utilizing technology mediated instruction. There are some obvious benefits such as low overhead because bricks and mortar are not necessary. Other advantages are students and instructors are not bound by geographic and/or scheduling limitations and students' limitation by faculty members is not a constraint. Along with traditional educational institutions, a new group of educational service providers utilizing technology mediated education has cropped up. Some, if not many, may not embrace the rigorous quality control standards we expect to find with most traditional academic institutions. Most traditional colleges and universities are classified as non-profit, whereas many of the online institutions are classified as for- profit. This in and of itself does not make them "bad" or of a lower quality. However, there are some educators who believe that for-profit institutional programs may not measure up to the traditional not-for-profit offerings.

Technology and digital learning tools promise to fundamentally change how instructors teach and how students learn, irrespective of the learning environment or institution. These advances are being met with a mix of resistance and acceptance, with some educators concerned that the new technologies may diminish their role in the educational process (Pearson, 2018). Just as with GE, organizational change threatens a comfortable and previously successful status quo for both administrators and faculty. To effectively deploy technology mediated education administrators must change their focus, and faculty members need training in both the technology and organization of their class materials and activities to take advantage of the digital learning tools. Student recruitment activities change, with less or no campus visits, student ambassadors or class visits.

Unfortunately, today's technology mediated instruction design often continue to follow design principles used in classroom lecture settings, repackaging rather than reengineering to take advantage of the unique capabilities presented by modern technology (Oliver \& Herrington, 2003). While this comment is from the early stages of technology mediated instruction, it is still relevant today. These authors are from Australia where their population is not dense, and the distances are great. Utilizing technology to deliver education opens many doors for students in remote locations who would otherwise not be able to continue their education. 
Program quality assurance standards are less clear and more difficult to define with technology mediated educational programs. The Goal of this paper is to identify quality measures based on how technology mediated education is currently being described, defined and evaluated. We have a long history of evaluating bricks and mortar academic institutions, with quality standards established by the faculty, alumni, accreditation agencies and professional organizations. This is not so with the newer technology mediated programs, which often stand alone and not associated with a traditional educational institution. The one common denominator for all technology mediated programs is their description and marketing through their web sites, which will be accessed to collect data for our preliminary assessment.

\section{The growth of technology mediated education}

Too often the effort that goes into implementing technology mediated education fails to lead to effective learning (Oliver \& Herrington, 2003). For all its wonder, those applying modern technologies in education must still bear in mind that, at least at the undergraduate level, students on the "receiving end" are young adults for whom the college process is one of socialization, learning about life, organizing and managing time, and learning about how to work with other people. This needs to remain in the fabric of $21^{\text {st }}$ century undergraduate technology mediated education.

Use of digital resources can improve access and reduce costs at a time when tuition is continually increasing, often pricing students out of continuing their education. Because this is a preliminary study, blended programs will not be considered, our assessment for cost will be limited to selected not-for-profit colleges and university online programs and for-profit online institutions.

\section{Technology Mediated Education Challenges}

College students and young $Z$ generation prefer to interact with others using technology (Siau \& Chen, 2016). The resounding success of Facebook, Twitter and other social networks and personal communication products and services tells us that there is support for these research findings. Bringing the same technology experiences into the learning environment may not be as well supported. Too often the efforts that go into implementing technology mediated learning fail to lead to effective learning. Key technology mediated education design constructs refer to using knowledge in real life (content), providing complex tasks with real world relevance (activities), and assessment integrated into the learning activities (Oliver \& Herrington, 2003). While these observations are more than 15 years old, they are still relevant. Plugging in a face-to-face class plan into a technology mediated educational program does not take advantage of the technology and may not create the most robust educational experience.

However, more than $60 \%$ of students surveyed believe that utilizing learning technologies increases their engagement with course materials. More than half the students surveyed believe that regularly engaging with instructors and classmates during online classes is important (Pearson, 2018). The challenge is to rethink the educational process to take maximum advantage of the education support capabilities found when utilizing technology, and not assume that an effective educational experience can be achieved by delivering a traditional face-to-face experience without significant class redesign.

\section{INSTITUTIONAL COURSE MODELS USED FOR ONLINE EDUCATION}

There are several institutional models currently being used to deliver online/technology mediated education. We will not consider blended programs in our analysis, as the traditional program forms the backbone and may cause some distortion in results. We will also not try to identify the details of the online experience such as scheduling, etc. Our selection of a program for comparison will be based on the program being completely online. It is not possible to consider every program available, so we elected to include three of the largest for profit institutions: University of Phoenix, Capella and the University of Southern New Hampshire; and two not-for-profit programs, St. Leo University online and Walden-Purdue Global. We will compare data from both not-for-profit and for-profit programs. 
Institutional Models:

- Open schedule. Students are provided a listing of all required coursework and deadlines for deliverables and work at their own pace within their own schedule and the deadlines provided.

- Hybrid. This approach combines traditional classes and open schedule.

- Computer based. Course is delivered through computer resources in a designated lab on a defined schedule.

- Fixed time. Logon at a designated time and complete class activities as a group. (Consumer affairs, 2018)

It appears that the open schedule model is the one most utilized by the institutions studied. Most of the student population likely lives beyond reasonable commuting distance of any facilities they might have, therefore would prefer to be totally online for their coursework.

\section{The Challenges of For-Profit online Educational Institutions}

Not all for profit online educational institutions are similar. Some institutions try to provide an educational experience that parallels that of a traditional program. They provide classes that qualify for transfer credit to other institutions, and they seek regional and specific course of study accreditation just as traditional institutions do. Other online programs are not as willing to meet the requirements for full program accreditation, and students find that most if not all coursework will not transfer should they decide to change programs. For many, especially those who are dissatisfied with their online experience, this can be a serious concern.

Determining and comparing costs for online and traditional programs is challenging. There is no differentiation for cost of in-state or out-of-state tuition; no housing, board and transportation costs with online programs, and fees and special assessments can often be confusing. Startling facts reported by the Federal General Accounting Office 2010 report (GAO1, 2010) include: 1) More than 54\% of students leave for-profit schools without a degree or certificate; 2) $96 \%$ of for-profit students leave with student debt, even if they do not earn a degree or certificate; 3) One of five students at for-profit schools will default on their student loans within 3 years. In the 2012 GAO Senate HELP report $(\mathrm{GAO} 2,2012)$ it was noted that the 15 largest for-profit programs received $86 \%$ of their revenue from federal student loan programs, spent almost one quarter of their income on student recruitment vs $17 \%$ on academic instruction, and accounted for $44 \%$ of all federal student loan defaults.

In one review, Consumer Affairs (2019) pointed out admissions requirements may be as low as a high school diploma or GED (if you have neither they will often sell you a GED course of study program), 16 years or older, and not being expelled from a previous institution. They may or may not accept transfer credits from either regionally or nationally accredited programs, which include virtually all online programs. One student reported that he was accepted into a graduate study program based on one marketing phone call with no transcripts, references or other supporting data. Further complaints include ineffective instructions, and financial and billing issues.

\section{QUALITY CONTROL MEASURES FOR TECHNOLOGY MEDIATED HIGHER EDUCATION}

Quality metrics are objective standards for measuring product quality. There is no common set of metrics, but they should be measurable, trackable and tied to goals (Sherman, 2018). This study proposes to assess business schools offering technology mediated higher education using five quality metrics: 1) external review and accreditation; 2) affordability; 3) admissions and graduation; 4) online students reviews and 5) accolades, issues, lawsuits and government fines. These metrics were selected because they represent a broad range, all believed to be useful and of interest to students investigating technology mediated educational programs. 


\section{Issues in Information Systems \\ Volume 20, Issue 1, pp. 108-118, 2019}

\section{External Review and Accreditation}

Utilizing university websites and other internet available resources, we determined for each university in the study their external review and accreditation and the results are shown in Table 1.

There is regional, national or other generally accepted accreditation based on comprehensive review guidelines similar to those followed by the Higher Learning Commission. Examples of regional accreditation agencies include:

MSCSA. Middle States Commission on Higher Education

NECHE. New England Commission on Higher Education

SACSCOC. Southern Association of Colleges and Schools Commission on College (Accreditation, 2018)

National accreditation is not as highly thought of as regional accreditation, in part because degree requirements are not as standardized as with regional accreditation, and credits are not as widely accepted for transfer. For professions needing to meet state or national licensing requirements, these credits may not be acceptable. Also, there are numerous bogus/fake national accreditation agencies making it more difficult to ensure quality standards are met (National Accreditation, 2018).

Table 1. External Review and Accreditation

\begin{tabular}{|l|l|l|}
\hline University & Programmatic & Accreditation \\
\hline University of Phoenix & Numerous & Higher Learning Com* \\
\hline Capella University & Numerous & Higher Learning Com* \\
\hline St. Leo University Online & Numerous & Southern Assn of Colleges and Schools \\
\hline Kaplan-Purdue Global University & Numerous & Higher Learning Com* \\
\hline University of Southern New Hampshire & Numerous & N.E. Council on Higher Education \\
\hline
\end{tabular}

*The Higher Learning Commission (www.hlcommission.org), previously the North Central Association, is a legitimate regional accreditation body that provides external review of core components, including: 1) Mission; 2) Integrity, ethical and responsible conduct; 3) Teaching and learning quality, resources and support; 4) Teaching and learning evaluation and support; and 5) Resources planning and institutional effectiveness

In the U.S.A. regional accreditation of the institution is required for program accreditation eligibility (ACBSP, 2018). Program accreditation based on specific guidelines focused on a discipline such as business, accounting, nursing, etc.

AACSB: Association to Advance Collegiate Schools of Business provides quality assurance, business education intelligence and professional development services. There are more than 800 accredited business schools worldwide (AACSB, 2018).

ACBSP: Accreditation Council for Business Schools and Programs was founded in 1988 and has accredited over 1,000 business programs worldwide. In the U.S.A. regional accreditation of the institution is required for accreditation eligibility. The accreditation activities focus on recognizing teaching excellence, determining student learning outcomes and continuous improvement (ACBSP, 2018).

Data on various standards of quality are collected, measured and evaluated by an outside organization (external review) to determine eligibility for accreditation. All the institutions in the study are accredited act the regional level and include some accreditation at the programmatic level.

\section{Affordability}

Utilizing university websites and other internet available resources, we determined for each university in the study their value and affordability. In a preliminary review of web sites for online technology mediated educational programs we find that there is a scarcity of directly comparable tuition and fees data. This made it necessary to look at other websites that display comparisons. Obviously, each program wants to show potential students why they should be chosen and focus their web content on marketing rather than program specifics. 


\section{Issues in Information Systems \\ Volume 20, Issue 1, pp. 108-118, 2019}

Table 2 shows that University of Phoenix has the highest tuition per credit, while University of Southern New Hampshire has the lowest tuition per credit without reoccurring fee.

\section{Admission and Graduation}

Admission and graduation data was somewhat elusive at times, and not always directly comparable. For example, graduation rates might be after four years, six years, and eight years, so are not precisely comparable, and it is not always clear what time frame is being reported. Most online students are not full time, so graduation time expectations would not be comparable to full time on campus students. Admissions requirements are modest, perhaps less stringent than most full time on campus program requirements.

Table 3 shows that admissions to the online universities has no requirements or very low requirements and they also tend to have a low graduation rate compared to traditional universities.

Table 2. Affordability

\begin{tabular}{|l|l|l|}
\hline University & Tuition Per Credit & Fees \\
\hline University of Phoenix & $\$ 398$ & $\$ 721$ per year \\
\hline Capella University & $\$ 354$ & $\$ 175$ per quarter \\
\hline St. Leo University Online & $\$ 350$ & $\$ 25$ per course \\
\hline Kaplan-Purdue Global University & $\$ 371$ & $\$ 295$ per semester \\
\hline University of Southern New Hampshire & $\$ 320$ & No reoccurring \\
\hline
\end{tabular}

Table 3. Admissions and Graduation

\begin{tabular}{|c|c|c|}
\hline University & Admissions & Graduation \\
\hline $\begin{array}{l}\text { University of } \\
\text { Phoenix }\end{array}$ & $\begin{array}{l}\text { Admission to Bachelor's programs requires a high } \\
\text { school diploma or GED, } 16 \text { years or older, and not } \\
\text { being expelled from another program. A very open- } \\
\text { door admissions policy. }\end{array}$ & $\begin{array}{l}\text { Only } 36 \% \text { of enrolled students } \\
\text { ever become sophomores. } \\
\text { Graduation rates not shown. }\end{array}$ \\
\hline $\begin{array}{l}\text { Capella } \\
\text { University }\end{array}$ & $\begin{array}{l}\text { For grad admission, a bachelors from an accredited } \\
\text { institution and a minimum } 2.3 \text { GPA. Undergraduate } \\
\text { requirements not stated. }\end{array}$ & The graduation rate is $17 \%$. \\
\hline $\begin{array}{l}\text { St. Leo } \\
\text { University } \\
\text { Online }\end{array}$ & $\begin{array}{l}\text { Admission to bachelor's program requires proof of } \\
\text { high school graduation and submission of } \\
\text { standardized test scores. Provisional admission may } \\
\text { be granted for those not meeting requirements. }\end{array}$ & The graduation rate is over $50 \%$. \\
\hline $\begin{array}{l}\text { Kaplan- } \\
\text { Purdue } \\
\text { Global } \\
\text { University }\end{array}$ & $\begin{array}{l}\text { Requirements include demonstrated English } \\
\text { proficiency, proof of technology competency and } \\
\text { high school graduation or GED. Graduate school } \\
\text { admission requires a } 2.5 \text { GPA. }\end{array}$ & The graduation rate is $24.5 \%$. \\
\hline $\begin{array}{l}\text { University of } \\
\text { Southern } \\
\text { New } \\
\text { Hampshire }\end{array}$ & $\begin{array}{l}\text { Requirements include proof of high school } \\
\text { graduation with a } 2.5 \text { GPA or above. Provisional } \\
\text { admissions may be granted for those not meeting } \\
\text { requirements. }\end{array}$ & $\begin{array}{l}\text { They have an } 84 \% \text { acceptance } \\
\text { rate and an under } 50 \% \text { graduation } \\
\text { rate. }\end{array}$ \\
\hline
\end{tabular}

\section{Online Student Rviews}

Guide to Online Schools (2019) (https://www.guidetoonlineschools.com/about) is a web site that helps prospective students find the right online college based on degree, tuition, student recommendation rate, and military benefits, among other attributes. It has a partner site GradReports.com, which has collected more than 30,000 reviews that were written by students about online schools from 2,243 colleges. Using python web scraping tool, all students' reviews on the selected five universities were extracted. The total reviews extracted are 3,596 (see table 4) as of 3/31/2019. University of Phoenix received the highest reviews of 2,319, while Kaplan-Purdue Global University and Saint Leo University Online have the lowest review of 146. 


\section{Issues in Information Systems \\ Volume 20, Issue 1, pp. 108-118, 2019}

Using python, a Word Cloud is created based on the reviews on each university and the results are shown in Charts 1-5. Word Cloud is a data visualization technique used for representing text data in which the size of each word indicates its frequency. It can be seen that the most frequently used words in all reviews are program, school, students, degree, online, and professor/instructor/teacher, followed by experience, assignment, advisor, money, job, and financial aid. Those words represent the aspects that students most likely discuss in the reviews, therefore representing factors (excluding common words like school, program, student, etc.) that may impact the rating of a student. The factors identified include professor, advisor, financial aid, job and experience.

Table 4. Sentiment Analysis for Online Student Reviews

\begin{tabular}{|c|c|c|c|c|c|c|}
\hline \multirow{2}{*}{ University } & \multirow{2}{*}{$\begin{array}{c}\text { Average } \\
\text { Sentiment } \\
\text { Score } \\
\end{array}$} & \multirow{2}{*}{$\begin{array}{l}\text { Average \# of } \\
\text { Sentiment } \\
\text { Words }\end{array}$} & \multicolumn{3}{|c|}{ Sentiment Classification } & \multirow{2}{*}{ Total } \\
\hline & & & Negative & Neutral & Positive & \\
\hline $\begin{array}{l}\text { University of } \\
\text { Phoenix }\end{array}$ & 0.65 & 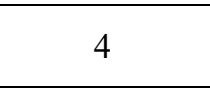 & $27.73 \%(643)$ & $6.73 \%(156)$ & $65.55 \%(1520)$ & 2319 \\
\hline $\begin{array}{l}\text { Capella } \\
\text { University }\end{array}$ & 0.98 & 6 & $18.81 \%(127)$ & $3.26 \%(22)$ & $77.93 \%(526)$ & 675 \\
\hline $\begin{array}{l}\text { University of } \\
\text { Southern New } \\
\text { Hampshire }\end{array}$ & 0.89 & 7 & $18.39 \%(57)$ & $5.48 \%(17)$ & $76.13 \%(236)$ & 310 \\
\hline $\begin{array}{l}\text { Kaplan-Purdue } \\
\text { Global } \\
\text { University }\end{array}$ & 0.87 & 6 & $15.07 \%(22)$ & $5.48 \%(8)$ & $79.45 \%(116)$ & 146 \\
\hline $\begin{array}{l}\text { Saint Leo } \\
\text { University } \\
\text { Online }\end{array}$ & 0.86 & 5 & $23.97 \%(35)$ & $4.79 \%(7)$ & $71.23 \%(104)$ & 146 \\
\hline Total & & & 884 & 210 & 2,502 & 3,596 \\
\hline
\end{tabular}

We used a sentiment analysis to classify opinions/ reviews on each university and determine their attitudes using AFINN Lexicon. The AFINN lexicon is a list of English terms manually rated for valence with an integer between -5 (negative) and +5 (positive) by Finn Årup Nielsen between 2009 and 2011. It currently includes 2,477 words. For example, words such as superb, outstanding, and excellent receive a 5 rating, while words such as bastard and prick receive a -5 score.

First, each review was split into words, all sentiment words were extracted from each review, the average score of all sentiment words were calculated for each review. If average score is greater than zero, a review is classified as positive, if average score is less than zero, a review is negative, and if average score is zero, a review is considered as neutral. A python script is created to automate this process and the results are shown in table 4. The average rating of all five universities are between 0 and 1 with Capella University received the highest rating of 0.98 and university of Phoenix received the lowest rating of 0.65 . The average number of sentiment words in each review ranges from 4 to 7 words.

Kaplan-Purdue Global University received the highest number of positive reviews (79\%) and the lowest number of negative reviews (15\%), while University of Phoenix received the lowest number of positive reviews $(66 \%)$ and the highest number of negative reviews (28\%). In sum, the majority of students' reviews of online university programs are positive. There exist differences in student reviews by university. It seems that Kaplan-Purdue Global University received most favorable review and University of Phoenix received the least favorite reviews among the five universities. There are no notable differences on the student reviews among the other three universities (Capella University, University of Southern New Hampshire, and Saint Leo University Online).

\section{Selected Online Education Quality Issues}

The move from full-time on-campus higher education to technology mediated and online programs has not been without problems. Some obvious issues concern student recruitment, faculty recruitment, financing, 


\section{Issues in Information Systems \\ Volume 20, Issue 1, pp. 108-118, 2019}

evolving curriculum issues, very rapid growth, and the dominance of for-profit institutions looking to maximize revenue. There are programs that have received positive recognition, but there are also many that have been subject to everything from government fines to student lawsuits. A few of the more prominent issues, including accolades, lawsuits and government fines for the five universities are discussed in this section.

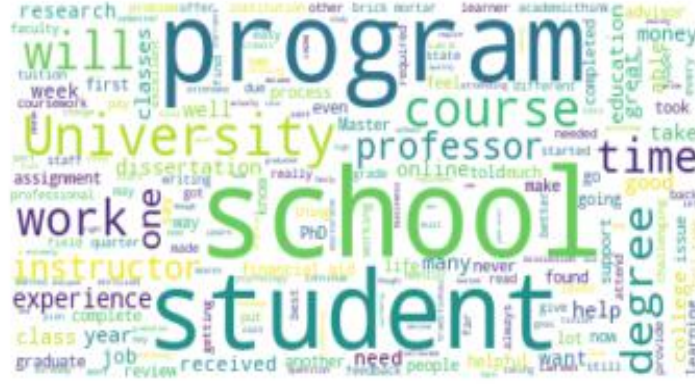

Figure 1. Capbella University

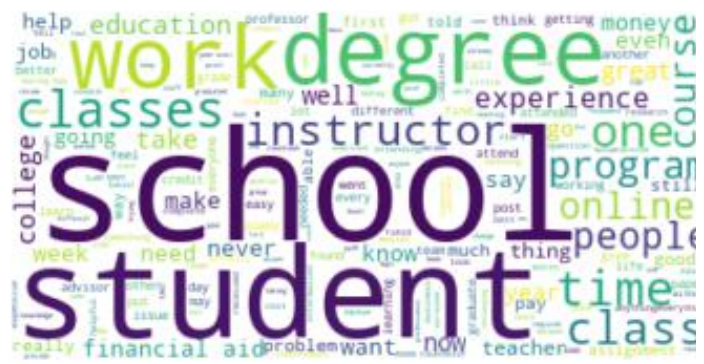

Figure 2. University of Phoenix

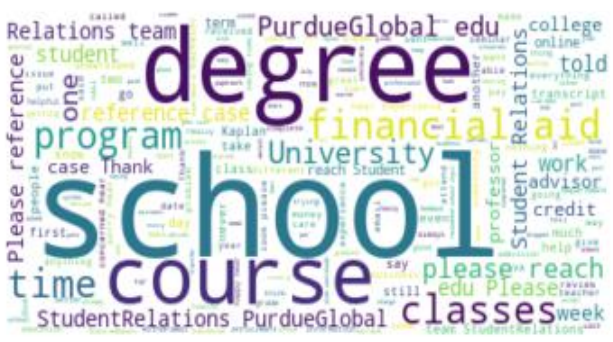

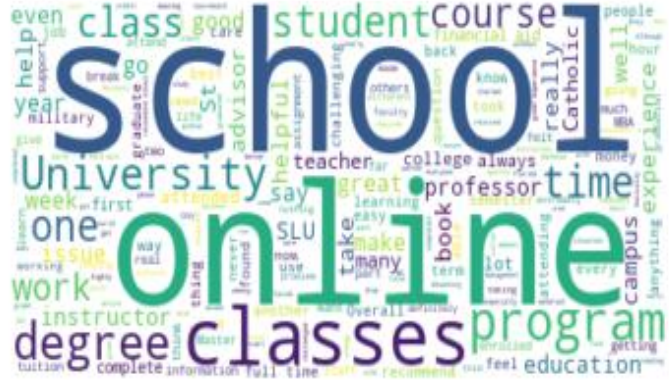

Figure 4. Saint Leo University Online

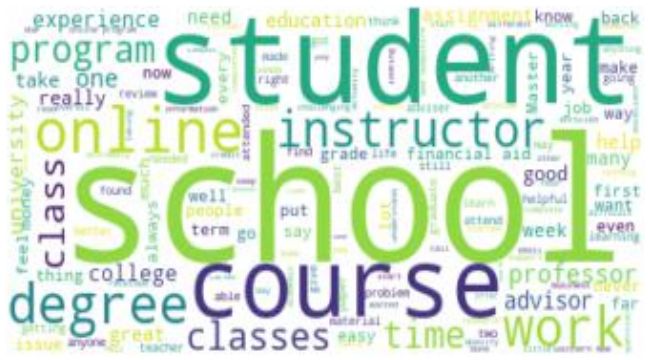

Figure 5. University of Southern New Hampshire

Figure 3. Kaplan-Purdue Global University

\section{University of Phoenix}

- A review of several web sites, including Consumer Affairs and Better Business Bureau, provide evidence of dissatisfaction from students. Student satisfaction ratings from 2 to 3 out of five are common, and complaints include frequently changing advisors, inconsistent faculty feedback, aggressive billing, collection and financial issues.

- The Department of Defense has shown dissatisfaction with the U. of Phoenix, suspending their ability to recruit on European military bases and receive federal funding for educating members of the U.S. military in 2015. The decision was overturned after protests by senators McCain (Ariz), Flake (Ariz) and Alexander (Tenn) the following year. 
- Wikipedia reports that the University of Phoenix has paid more than 100 million dollars in federal fines and lawsuit settlements in recent years

(https//en.wikipedia.org/university_of_phoenix\#criticisn_and_controversies).

\section{Capella University}

- Eighty six percent of the faculty hold doctorates, and Capella received the Council of Higher Education award for Outstanding Institutional Practice and Student Learning Outcomes.

- The Minnesota Office of Higher Education logged 71 complains from Capella students from 2013 to 2016 , about $1 / 3$ of all complaints recorded statewide.

- A review of the Consumer Affairs website provides evidence of some student dissatisfaction with average ratings of 3 out of 5 (www.consumeraffairs.com/education/capella-university.html).

- In a lawsuit filing, it is alleged that Capella spends $\$ 4,538$ per student on marketing, $\$ 1,650$ per student on instruction, and school profit is $\$ 2,912$ per student (www.google.com/search?q=capella+university+complaints+and + lawsuits).

\section{St. Leo University Online}

- Founded as a private university in 1889.

- More than 2/3 of their business students score on or above the national average on the ETS Major Field Test.

- Accepts transcript credit from regionally accredited institutions.

\section{Kaplan-Purdue Global University}

- In 2015 Kaplan was sued by the Federal Department of Justice for hiring ill-qualified instructors.

- Prior to the merger Kaplan was rated one star out of five by students (www.consumeraffairs.com>education).

- Recent rating averages 2.5 out of 5. (www.gradereports.com/colleges/purdue-university-global)

\section{University of Southern New Hampshire}

- A private for-profit university.

- Concerns with billing, collection, and quality of instruction.

- New Hampshire Business Review named Best MBA Program for 2019.

\section{STUDY RESULTS AND CONCLUSION}

A few surprises are evident: even the programs that have serious issues, shortfalls and complaints are regionally accredited. With the reported issues concerning low faculty wages, poor quality instruction, financial pressures on students to apply for federal student aid, complete reliance on federal government loans for revenue, and many other programmatic issues challenging ethical conduct, teaching and learning expectations, and institutional effectiveness, it is somewhat surprising that the accrediting organizations continue to grant accreditation to even the most blatant for profit programs. With student populations in the millions, there is a need for technology mediated higher education programs, the question seems to be more of quality control. It is also clear that without government loans all the largest programs would cease to exist. One might question a student paying tuition with mostly borrowed funds participating in a program that spends almost four times as much of their tuition dollars on student recruitment as on teaching and learning.

The bottom line is that technology mediated educational programs are here to stay. Programs with established admission standards, external review and regional accreditation, fair tuition pricing and minimum student and other complaints are challenging traditional programs for student tuition dollars, playing an important role in the delivery of higher education in the United States. 


\section{FURTHER STUDY}

This has been a very preliminary study and overview of technology mediated higher education, with the objective of getting a better understanding of the strategies and issues when delivering technology mediated higher education in the $21^{\text {st }}$ century. The study segment is limited to five US universities and barley scratches the surface. A study including smaller online only programs, imbedded programs in brick and mortar institutions, and programs in other countries offers the potential to increase our understanding of the issues, impact and relative value of technology mediated higher education.

\section{REFERENCES}

AACSB (2018). Found at: www.aacsb.edu/about

ACBSP (2018). Found at: www.acbsp.org/page/valueaccreditation

Accreditation (2018). Found at: www.chea.org/regional-accrediting-organizations

CNN Wire (2018). GE Slashes 119-Year Old Dividend to a Penny, Found at: https://www.kimt.com/content/national/498992451.html

Comstock, B. (2018). Can GE Make the Most of Its Reset Moment? Found at: https://knowledge.wharton.upenn.edu/article/ge-reset-moment/

Consumer Affairs (2018). Found at: www.consumeraffairs.com/education/online-courses/\#

Consumer Affairs (2019). Found at: www.consumeraffairs.com/education/online-colleges/phoenix.html

GAO1 (2010). Undercover Testing Finds Colleges Encouraged Fraud and Engaged in Deceptive and Questionable Marketing Practices, Found at: https://www.gao.gov/products/GAO-10-948T

GAO2 (2012). For Profit Higher Education: The Failure to Safeguard the Federal Investment and Ensure Student Success, Found at: https://www.help.senate.gov/imo/media/for_profit_report/Contents.pdf

Google (2018). Found at:_www.google.com/search?q=technology;+use+it+more,+use+it+better

Li, S., Records, H. \& R. Behling (2018). A Comparison of Information Technology Mediated Customer Services between the U.S. and China. Issues in Information Systems 19(1), 1-10.

National Accreditation (2018). Found at: www.geteducated.com/agencies-for-college-accreditation

Oliver, R. \& Harrington J. (2003). “Exploring Technology Mediated Learning From a Pedagogical Perspective", found at: http://researchrepository.murdoch.edu.au/6835/

Pearson (2018). How do Faculty and Students Really Feel about Ed Tech? Found at: www.pearsoned.com/campaigns/dr/faculty-tech-attitudes-infographic.html?ut

Pearson2 (2018). Found at: www.pearson.com/us/higher-education.

Saadé, R., Buyukkurt, M. \& Akhori C. (2011). Technology Mediated Learning: Observations in Two Technologies. Issues in Informing Science and Information Technology, 8, 395-408

Sherman, F. (2018). What are Quality Metrics, found at https://bizfluent.com/facts-6886409-qualitymetrics-.html 


\section{Issues in Information Systems}

Volume 20, Issue 1, pp. 108-118, 2019

Siau, K. \& X. Chen (3016). Technology Mediated Synchronous Virtual Education: An Empirical Study. Journal of Database Management, 27(4), 39-63. 